Ekuitas: Jurnal Pendidikan Ekonomi

Volume 6, Number 2, Tahun 2018, pp. 88-96

P-ISSN : 2354-6107 E-ISSN : 2549-2292

\title{
Pemanfaatan Data Transaksi Keuangan Dunia Usaha/Dunia Industri Untuk Meningkatkan Aktivitas Dan Hasil Belajar Siswa Pada Pembelajaran Ekonomi
}

\author{
Putu Agus Eka Sedana Jaya*
}

SMA Negeri 2 Busungbiu, Buleleng-Indonesia

\section{A R T I C L E I N F O}

Article history:

Received 15 May 2018

Received in revised form

13 June 2018

Accepted 15 July 2018

Available online 29 August 2018

Kata Kunci:

Data Transaksi Keuangan,

Dunia Usaha/Dunia

Industri, Aktivitas dan Hasil

Belajar

Keywords:

The Data of Financial

Transaction of Business

World/The World of

Industry, Students Activities

and Result Study
A B S T R A K

Penelitian ini bertujuan meningkatkan aktivitas dan hasil belajar siswa pada pembelajaran ekonomi melalui pemanfaatan data transaksi keuangan Dunia Usaha/Dunia Industri. Penelitian ini dilaksanakan dalam dua siklus, di mana setiap siklus terdiri atas tahap perencanaan, pelaksanaan, observasi, evaluasi, dan refleksi. Subjek penelitian ini adalah siswa kelas XII IPS 1 SMAN 2 Busungbiu semester ganjil tahun pelajaran 2017/2018 yang berjumlah 30 orang. Objek penelitian ini adalah peningkatan aktivitas dan hasil belajar siswa. Hasil penelitian menunjukkan terjadi peningkatan aktivitas belajar siswa dari kategori cukup dengan rerata skor 56,54 pada siklus I menjadi kategori baik dengan rerata skor 66,96 pada siklus II. Hasil belajar siswa pada kompetensi pengetahuan mengalami peningkatan rerata nilai dari 57,17 dengan ketuntasan belajar klasikal sebesar $53,00 \%$ pada siklus I menjadi sebesar 75,17 dengan ketuntasan belajar klasikal sebesar $90,00 \%$ pada siklus II. Pada kompetensi keterampilan juga mengalami peningkatan dari 64,10 dengan ketuntasan belajar klasikal sebesar $50,00 \%$ pada siklus I menjadi sebesar 75,00 dengan ketuntasan belajar klasikal sebesar $87,00 \%$. Berdasarkan hasil penelitian tersebut dapat disimpulkan bahwa pemanfaatan data transaksi keuangan Dunia Usaha/Dunia Industri dapat meningkatkan aktivitas dan hasil belajar siswa pada pembelajaran ekonomi.

A B S T R A C T

This research aimed at improving the activities and result study of Economy subjectthrough the utilization of of data transaction of Business world/The World of Industry. This research was done into two cycles, which every cycle consist of some phases such as planning, implementation, observation, evaluation, and reflection. The subjects of this research was the students of XII IPS 1 SMAN 2 Busungbiu on the first semester in the academic year of 2017/2018 that consist of 30 students. The object of the research was the improvement of the students' activities and the result study of the students. The result shows that there was an improvement of the students' learning activities from the category of average by the mean score of 56,54 in the cycle I to be the category of Good with the mean score of 66,96 in cycle II. The students' result study in the cognitive competency experienced an improvement of the mean score at 57,17 by the completeness of the classical study at $53,00 \%$ on cycle I to be 75,17 by the completeness of classical study in the amount of $90,00 \%$ on cycle II. In the psychomotor competency also there was an improvement in the amount of 64,10 by the completeness of the classical study at $50.00 \%$ on cycle I to be 75,00 by the completeness of classical study at $87,00 \%$. Based on the result of the research above, it can be concluded that the manipulation of the world financial transaction / industry can improve the activities and the result study of the students in the subjects of Economy.

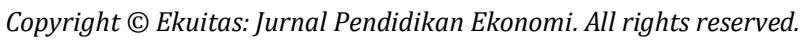

\footnotetext{
* Corresponding author.

E-mail addresses: aguseka.gosi@ gmail.com (Putu Agus Eka Sedana Jaya)
} 


\section{Pendahuluan}

Salah satu tingkat kompetensi pada mata pelajaran ekonomi adalah memahami konsep dan mampu menerapkan siklus akuntansi perusahaan jasa dan dagang. Tingkat kompetensi sebagai kriteria capaian ini sesuai dengan kompetensi lulusan yang dirumuskan pada Standar Kompetensi Lulusan, yakni sikap, pengetahuan, dan keterampilan. Kompetensi sikap dicapai melalui pembelajaran tidak langsung (indirect teaching), yaitu melalui keteladanan, pembiasaan, dan budaya sekolah; dengan memperhatikan karakteristik mata pelajaran, serta kebutuhan dan kondisi peserta didik, sedangkan kompetensi pengetahuan dan keterampilan dicapai dalam proses pembelajaran.

Sejalan dengan ketercapaian kompetensi sikap terdapat beberapa indikator yang menunjukkan aktivitas siswa dalam pembelajaran, yakni 1) turut serta dalam melaksanakan tugas belajarnya, 2) terlibat dalam pemecahan masalah, 3) bertanya kepada siswa atau kepada guru apabila tidak memahami persoalan yang dihadapinya, 4) berusaha mencari berbagai informasi yang diperlukan untuk pemecahan masalah, 5) melaksanakan diskusi kelompok sesuai dengan petunjuk guru, 6) menilai kemampuan diri dalam memecahkan soal atau masalah sejenis, dan 7) kesempatan menggunakan atau menerapkan apa yang telah diperolehnya dalam menyelesaikan tugas persoalan yang dihadapinya. Dengan meningkatnya aktivitas siswa, maka keterlibatan siswa dalam pembelajaran dapat dioptimalkan dan pengalaman siswa untuk memahami konsep dan mampu menerapkan siklus akuntansi perusahaan jasa dapat tercapai dengan baik, sehingga akan dapat meningkatkan kualitas proses dan hasil belajar, termasuk hasil belajar Mata Pelajaran Ekonomi.

Dalam memahami konsep siklus akuntansi perusahaan jasa diperlukan pemahaman analisis transaksi sebagai langkah awal untuk menyusun persamaan dasar akuntansi ataupun jurnal umum. Hal ini sangat diperlukan karena kebanyakan orang mengira bahwa belajar adalah menghafal. Kenyataannya, orang yang hafal belum tentu paham tetapi orang yang paham sudah pasti mengerti. Begitu pula dalam menganalisis transaksi dibutuhkan pemahaman yang harus benar-benar dikuasai sepenuhnya.

Transaksi yang didapat berasal dari data transaksi keuangan pada Dunia Usaha/Dunia Industri yang ada di daerah sekitar sekolah. Mengadopsi pada pendidikan sistem ganda (PSG) pada pendidikan kejuruan, maka sistem pendidikan dapat dilaksanakan pada dua tempat yaitu sekolah dan dunia usaha/dunia kerja. Sehingga dalam hal ini, data transaksi keuangan yang didapatkan pada Dunia Usaha/Dunia Industri akan dianalisis sehingga bisa dimasukkan ke dalam persamaan dasar akuntansi ataupun jurnal umum dengan benar. Kegiatan belajar ini sesuai dengan tuntunan Kurikulum 2013, dimana sumber belajar tidak hanya berasal dari buku, media cetak dan elektronik, juga berasal dari lingkungan alam sekitar.

Proses pembelajaran pada hakikatnya memerlukan keterlibatan mental dan fisik siswa. Berkaitan dengan hal tersebut, maka meningkatkan hasil belajar siswa dalam pembelajaran adalah salah satu tugas profesional guru. Dalam konteks ini, guru hendaknya memfasilitasi, memotivasi, dan menerapkan metode pembelajaran yang menumbuhkembangkan keterlibatan aktivitas siswa dalam berpendapat, meneliti, dan berbuat sesuatu. Oleh karena itu, aktivitas belajar siswa sangat bergantung kepada peran guru dalam mengelola pembelajaran. Artinya, kreativitas guru adalah salah satu faktor yang menentukan kualitas pembelajaran dan hasil belajar siswa.

Fakta di lapangan menunjukkan, bahwa aktivitas siswa dalam pembelajaran belum dapat berlangsung secara optimal. Hal ini berpengaruh terhadap kualitas proses dan hasil belajar siswa. Kondisi ini juga terjadi pada siswa-siswa di SMAN 2 Busungbiu. Hasil observasi pada siswa kelas XII IPS 1 SMA Negeri 2 Busungbiu semester ganjil tahun pelajaran 2016/2017 pada materi jurnal umum sangat kurang, yakni menunjukkan rata-rata nilai 52,5 dengan rentang nilai dari 0 sampai 100, serta ketuntasan klasikal 53\%. Rendahnya hasil belajar siswa ini juga diperkuat dari hasil ulangan harian I siswa kelas XII IPS 1 pada semester ganjil tahun pelajaran 2017/2018. Dari sejumlah 30 siswa yang mengikuti ulangan harian I, diperoleh rata-rata sebesar 51,00 dengan ketuntasan belajar sebesar $23 \%$ dan daya serap mencapai 51\%. Hasil ini dapat dijadikan sebagai bahan refleksi awal untuk melakukan tindakan perbaikan pembelajaran dalam upaya meningkatkan hasil belajar siswa.

Pembelajaran ekonomi pada materi akuntansi sudah mengarah pada pembelajaran saintifik, di mana penggunaan model pembelajaran problem based learning sudah dilaksanakan dengan baik, bahkan media pembelajaran berupa LKS tertsruktur sudah dipersiapkan untuk mendukung proses pembelajaran. Namun hasil akhirnyamenunjukkan hal yang bertolak belakang, siswa banyak yeng mendapatkan nilai di bawah KKM. Dari hasil observasi dan wawancara dengan siswa terdapat beberapa faktor yang menyebabkan rendahnya hasil belajar siswa, diantaranya (1) Siswa masih belum terbiasa dengan materi akuntansi; (2) Hanya dengan membaca sumber belajar dan mengerjakan LKS siswa kurang antusias dalam belajar; (3) Banyak siswa yang tidak mengerjakan LKS yang diberikan, melainkan memilih untuk mencontek teman 
yang dianggap pintar di kelasnya; (4) Sebagian besar siswa tidak mengenal bukti transaksi keuangan; (5) Siswa tidak paham dalam menganalisis transaksi keuangan yang tersedia; (6) Siswa kurang paham hanya dalam penyusunan persamaan dasar akuntansi dan jurnal dari transaksi yang tersedia dari sumber belajar; dan (7) ketika guru memberikan latihan untuk menyusun persamaan dasar akuntansi dan jurnal, siswa selalu kesulitan dan tidak pernah selesai.

Fakta tersebut memberikan gambaran bahwa pembelajaran yang dialami siswa masih kurang inovatif dalam membangkitkan rasa ingin tahu siswa. Selain itu, kecenderungan pembelajaran menggunakan modalitas yang lebih cenderung audiotorial. Padahal, kajian kurikulum menuntut agar dalam proses pembelajaran, siswa bekerja dalam kelompok-kelompok kecil atau bekerja mandiri, dalam rangka mempelajari teori dan contoh, mengerjakan tugas-tugas, menggunakan alat-alat bantu, mempelajari atau memilih pustaka. Pembelajaran juga diharapkan agar siswa terlibat secara keseluruhan dalam diskusi kelas. Dalam konteks ini, guru bertugas sebagai fasilitator untuk memberikan bantuan secara klasikal atau individual kepada siswa yang membutuhkan.

Di pihak lain, sumber belajar yang efektif dalam rangka memberikan pengalaman belajar yang nyata dan kontekstual jarang diberikan oleh guru terutama pada penyusunan jurnal umum perusahaan jasa. Data transaksi yang diberikan masih bersifat umum, sehingga siswa kurang memiliki keinginan belajar yang kuat dan rasa ingin tahu untuk menyelesaikan transaksi riil pada perusahaan. Oleh karena itu, perlu adanya dukungan dari Dunia Usaha/Dunia Industri untuk memberikan data-data transaksi keuangan yang akan diolah dan dianalisis sehingga mampu dicatat ke dalam persamaan dasar akuntansi dan jurnal umum.

Berdasarkan uraian tersebut, dapat dijelaskan bahwa pembelajaran belum berlangsung dengan baik. Beberapa fakta diantaranya, siswa kurang dalam beraktivitas untuk mempresentasikan hasil pekerjaannya dan siswa kurang memiliki pengalaman belajar yang mendukung dalam penyelesaian transaksi keuangan yang dicatat ke dalam persamaan dasar akuntansi dan jurnal umum. Berkaitan dengan hal tersebut, perlu dilakukan upaya tindakan perbaikan pembelajaran. Tindakan itu dilakukan untuk membantu, mengarahkan, dan membimbing siswa sehingga aktivitas siswa dan unjuk kerja dalam pembelajaran dapat ditingkatkan melalui pengamatan dan praktik kerja lapangan sehingga diyakini akan meningkatkan hasil belajar siswa. Pemahaman akan transaksi yang diperoleh akan mempermudah penyelesaian persamaan dasar akuntansi dan jurnal umum, dimana transaksi yang langsung dicatat kedalam buku besar dan terjadi kesalahan, maka letak kesalahan tersebut sulit ditemukan, sehingga dalam konteks ini, selanjutnya dilakukan penelitian pemanfaatan data transaksi keuangan Dunia Usaha/Dunia Industri untuk meningkatkan aktivitas dan hasil belajar siswa pada mata pelajaran Ekonomi.

\section{Metode}

Penelitian ini dilaksanakan di SMAN 2 Busungbiu Kabupaten Buleleng pada semester ganjil tahun pelajaran 2017/2018. Implementasi tindakan pada penelitian ini dilaksanakan mulai tanggal 18 Juli 2017 sampai dengan 28 September 2017. Tindakan pada penelitian tindakan kelas ini, yakni Pemanfaatan Data Transaksi Keuangan Dunia Usaha/Dunia Industri. Tindakan tersebut diimplementasikan dalam kegiatan pembelajaran yang berbasis pendekatan saintifik. Subjek penelitian ini adalah siswa kelas XII IPS 1, SMAN 2 Busungbiu yang berjumlah 30 orang dengan rincian 20 orang laki-laki dan 10 orang perempuan. Sedangkan objek penelitian ini adalah peningkatan aktivitas dan hasil belajar siswa dengan pemanfaatan data transaksi Dunia Usaha/Dunia Industri.

Penelitian berlangsung dalam dua siklus, di mana setiap siklus terdiri atas empat tahap, yakni perencanaan, tindakan, observasi dan evaluasi, dan refleksi. Siklus I terdiri dari 5 (lima) kali tatap muka sedangkan siklus II terdiri dari 3 (tiga) kali tatap muka. Kajian pada siklus I meliputi data transaksi keuangan DU/DI yang dicari oleh siswa dengan kelompok belajarnya kemudian dicatat ke dalam persamaan dasar akuntansi. Sedangkan kajian pada siklus II, yakni data transaksi keuangan DU/DI yang dirujuk oleh guru kemudian dicatat ke dalam jurnal umum. Prosedur penelitian pada masing-masing siklus sebagai berikut.

Kegiatan pada tahap perencanaan ini, meliputi: 1) pembuatan perangkat pembelajaran dan 2) pembuatan instrumen penelitian. Perangkat pembelajaran yang dibuat meliputi silabus, rencana pelaksanaan pembelajaran (RPP), dan lembar kerja siswa (LKS) terstruktur. Sedangkan instrumen dalam penelitian ini adalah pedoman observasi aktivitas belajar siswa, tes praktik/unjuk kerja untuk kompetensi keterampilan, dan tes kompetensi pengetahuan.

Pedoman observasi terdiri dari 4 parameter aktivitas siswa dalam pembelajaran, yakni 1) Kerjasama siswa, 2) Antusiasme/Partisipasi siswa, 3) Presentasi siswa, dan 4) Interaksi siswa. Tes yang digunakan meliputi tes keterampilan dalam menyusun persamaan dasar akuntansi dan tes pengetahuan 
dengan tes tertulis bentuk pilihan ganda. Soal-soal pada tes mengacu pada indikator pencapaian kompetensi dasar.

Tahap pelaksanaan tindakan merupakan implementasi rencana penelitian. Pelaksanaan tindakan pada siklus I terdiri dari lima kali tatap muka dan setiap tatap muka meliputi tiga kegiatan yakni 1 ) pendahuluan, 2) inti, dan 3) penutup.

Pada kegiatan pendahuluan, meliputi 1) menyampaikan kompetensi dasar, indikator pencapaian kompetensi, dan tujuan pembelajaran, 2) menjelaskan sistem penilaian yang digunakan, 3) menginformasikan sumber belajar yang akan digunakan berkaitan dengan data transaksi yang sudah dipersiapkan sebelumnya oleh siswa sendiri yang didapat dari Dunia Usaha/Dunia Industri daerah sekitarnya, 4) memotivasi siswa agar terlibat aktif, 5) membentuk kelompok yang anggotanya terdiri atas lima orang.

Kegiatan inti, meliputi 1) mengarahkan dan membimbing siswa untuk berkumpul dengan kelompoknya, 2) membimbing siswa dalam menganalisis transaksi yang didapatkan menjadi data transaksi yang siap untuk dianalisis, 3) membagikan lembar kerja siswa (LKS) terstruktur berupa data transaksi dan format analisis data transaksi dan persamaan dasar akuntansi, 4) membimbing siswa untuk berdiskusi dengan kelompoknya serta menjawab berbagai permasalahan yang disajikan pada LKS, dan 5) membimbing dan mengarahkan siswa agar menggunakan berbagai sumber pelajaran dalam melakukan kegiatan diskusi kelompok, 6) mempersiapkan dan membimbing siswa dalam mempresentasikan hasil diskusi kelompoknya, 7) memberikan kesempatan kepada siswa untuk berdiskusi guna memperjelas argumentasi dalam presentasi, 8) membimbing dan mengarahkan kegiatan diskusi kelas, dan 9) mengasosiasi pengetahuan siswa dengan mengajukan pertanyaan yang berkaitan materi yang dikaji.

Kegiatan penutup terdiri atas: 1) memberikan kesempatan kepada siswa untuk menanggapi atau mengomentari konsep-konsep analisis transaksi dan pencatatan yang tidak sesuai dengan hasil diskusi kelompoknya, 2) membimbing dan mengarahkan kelompok lainnya untuk memberikan argumentasi terhadap penyampaian konsep kelompok lain, dan 3) menyimpulkan dan memberikan penguatan terhadap konsep sesuai tujuan pembelajaran.

Tahap observasi dan evaluasi tindakan pada siklus I dilakukan dengan langkah-langkah, sebagai berikut: 1) melakukan observasi terhadap proses pembelajaran dengan cara mengisi tanda "cek ( $\sqrt{ }$ )" pada lembar observasi dan mendeskripsikan kejadian penting selama proses pembelajaran; dan 2) melakukan evaluasi hasil belajar siswa yang dilakukan dengan tes praktik dan tes tertulis.

Refleksi dilakukan pada akhir siklus I yang didasarkan pada hasil observasi dan penilaian hasil belajar siswa. Refleksi dilakukan untuk menganalisis kelemahan-kelemahan tindakan yang terjadi pada setiap siklus I. Berdasarkan kelemahan tersebut, selanjutnya ditentukan langkah-langkah perbaikan. Refleksi tindakan juga dilakukan untuk mengetahui keberhasilan-keberhasilan yang telah dicapai, sehingga dapat dipertahankan atau ditingkatkan pada siklus berikutnya.

Perencanaan, tindakan, observasi dan evaluasi, serta refleksi pada siklus II adalah perbaikan atau penyempurnaan dari siklus I. Berdasarkan hasil refleksi dari siklus I, maka dirancanglah perencanaan untuk siklus II yang bertujuan untuk memperbaiki kelemahan atau kekurangan yang ditemukan pada siklus I. Tindakan siklus II yang dilaksanakan sebanyak 3 pertemuan pada hakikatnya sama dengan tindakan pada siklus I dengan beberapa perbaikan sesuai dengan refleksi pada siklus I. Observasi dan evaluasi pada siklus II dilaksanaan saat pelaksanaan tindakan. Berdasarkan hasil observasi dan evaluasi pada siklus II tersebut, selanjutnya dilakukan refleksi siklus II untuk dapat menyimpulkan hasil penelitian.

Data yang dikumpulkan dalam penelitian ini terdiri dari aktivitas dan hasil belajar siswa terhadap pemaanfaatan data transaksi Dunia Usaha/Dunia Industri pada pembelajaran ekonomi. Data mengenai aktivitas siswa dikumpulkan dengan menggunakan pedoman observasi dan dianalisis berdasarkan skor yang diperoleh sesuai rubrik yaitu dari rentang $4-16$ kemudian dikalikan $\frac{100}{16}$. Hasil yang diperoleh disesuaikan dengan pedoman penggolongan sikap siswa yang selanjutnya dapat dinyatakan dalam kategori : Amat Baik(skor 88-100), Baik (skor 63-87), Cukup (skor 38-62), dan Kurang (skor <37)

Data hasil belajar siswa dianalisis secara deskriptif, yaitu dengan skor hasil belajar siswa yang diperoleh dari tes praktik dan ulangan harian.Setelah diperoleh skor pengetahuan dan keterampilan siswa, selanjutnya dicari skor rata-rata pengetahuan dan keterampilan siswa. Ketuntasan aspek pengetahuan dan keterampilan siswa dapat di tentukan dengan menggunakan daya serap siswa (DSS) dan ketuntasan klasikal (KK).

Siswa dikatakan tuntas jika DSS $\geq 75 \%$ dan $\mathrm{KK} \geq 85 \%$. Hal ini sesuai dengan kriteria yang ditetapkan oleh SMA Negeri 2 Busungbiu. Penelitian dikatakan berhasil jika skor rata-rata pengetahuan dan keterampilan siswa $\geq 75$ dan ketuntasan klasikal $(\mathrm{KK}) \geq 85 \%$. Sedangkan pendapat siswa yang memiliki pendapat setuju terhadap pemanfaatan data transaksi keuangan DU/DI dalam pembelajaran, minimal sebesar $85 \%$. 


\section{Hasil dan pembahasan}

Hasil

Hasil penelitian yang dilaksanakan pada Siklus I didapatkan hasil aktivitas belajar siswa pada pertemuan I sampai dengan pertemuan $\mathrm{V}$ yaitu diperoleh rata-rata keseluruhan aktivitas siswa sebesar 56,54 dengan kategori Cukup (C). Sebaran nilai aktivitas siswa pada siklus I disajikan sebagai berikut.

Tabel 1. Sebaran Nilai Aktivitas Siswa Pada Siklus I

\begin{tabular}{cccc}
\hline No & Jumlah Siswa & Kategori & Presentase \\
\hline 1 & 11 & Baik & $36,67 \%$ \\
2 & 12 & Cukup & $40,00 \%$ \\
3 & 7 & Kurang & $23,33 \%$ \\
\hline
\end{tabular}

Berdasarkan tabel di atas, menunjukkan bahwa sebaran nilai aktivitas pada siklus I masih terdapat $23,33 \%$ siswa yang mendapatkan nilai kurang (D). Besarnya persentase ini menyebabkan keseluruhan ratarata aktivitas siswabelum mencapai indikator keberhasilan yang ditetapkan yakni aktivitas siswa memiliki nilai baik (B).

Hasil belajar siswa untuk kompetensi pengetahuan dan keterampilan pada siklus I disajikan pada tabel berikut ini.

Tabel 2. Data Nilai Pengetahuan dan Keterampilan Siklus I

\begin{tabular}{cccc}
\hline NO & STATISTIK & PENGETAHUAN & KETERAMPILAN \\
\hline 1 & Jumlah Siswa & 30 & 30 \\
2 & Jumlah Nilai & 1.715 & 1.923 \\
3 & Rata-rata Nilai & 57,17 & 64,10 \\
4 & Jumlah Siswa Tuntas & 16 & 15 \\
5 & Jumlah Siswa Tidak Tuntas & 14 & 15 \\
6 & Daya Serap & $57,00 \%$ & $64,10 \%$ \\
7 & Ketuntasan Belajar Klasikal & $53,00 \%$ & $50,00 \%$ \\
8 & Nilai Tertinggi & 75 & 100 \\
9 & Nilai Terendah & 25 & 7,69 \\
10 & Standar Deviasi & 16,38 & 32,57 \\
\hline
\end{tabular}

Dari data di atas, rata-rata nilai pengetahuan dan keterampilan hanya mencapai 57,17 dan 64,10 dengan ketuntasan klasikal mencapai 53\% dan 50\%. Hal ini menunjukkan bahwa nilai hasil belajar masih jauh dari indikator kinerja yang ditetapkan sebesar 75 untuk rata-rata nilai siswa dan mencapai ketuntasan 85\% untuk ketuntasan klasikalnya. Kajian analisis hasil belajar siswa dalam sebaran nilai siklus I pada kompetensi pengetahuan dan keterampilan sebagai berikut.

Tabel 3. Sebaran Nilai Pengetahuandan Keterampilan Siswa Pada Siklus I

\begin{tabular}{ccccccc}
\hline \multirow{2}{*}{ No } & \multicolumn{3}{c}{ Pengetahuan } & \multicolumn{3}{c}{ Keterampilan } \\
\cline { 2 - 6 } & $\begin{array}{c}\text { Jumlah } \\
\text { Siswa }\end{array}$ & Kategori & Presentase & $\begin{array}{c}\text { Jumlah } \\
\text { Siswa }\end{array}$ & Kategori & Presentase \\
\hline 1 & 4 & Di atas KKM & $13,33 \%$ & 15 & Di atas KKM & $50,00 \%$ \\
2 & 12 & Mencapai KKM & $40,00 \%$ & 15 & Di bawah KKM & $50,00 \%$ \\
3 & 14 & Di bawah KKM & $46,67 \%$ & & & \\
\hline
\end{tabular}

Dari data di atas terdapat sebanyak 14 orang siswa masih kurang memahami kompetensi pengetahuan dan sebanyak 15 orang belum terampil dalam menyusun persamaan dasar akuntansi. Dengan demikian pemanfaatan data transaksi Dunia Usaha/Dunia Industri dalam proses pembelajaran perlu mendapatkan perhatian serius sehingga diperlukan perbaikan tindakan pada siklus II dengan tetap mempertahankan tindakan yang sudah baik pada siklus I.

Hasil penelitian yang dilaksanakan pada Siklus II didapatkan hasil aktivitas belajar siswa dengan rata-rata keseluruhan aktivitas siswa sebesar 68,96 dengan kategori Baik (B). Aktivitas siswa mengalami kenaikan sebesar 12,42 dari siklus I yang sebesar 56,54 atau naik sebesar $18 \%$ dari kategori Cukup (C) pada 
siklus I menjadi kategori Baik (B) pada siklus II. Sebaran nilai aktivitas siswa pada siklus II disajikan sebagai berikut.

Tabel 4. Sebaran Nilai Aktivitas Siswa Pada Siklus II

\begin{tabular}{cccc}
\hline No & Jumlah Siswa & Kategori & Presentase \\
\hline 1 & 1 & Amat Baik & $3,00 \%$ \\
2 & 29 & Baik & $97,00 \%$ \\
\hline
\end{tabular}

Dari tabel di atas, menunjukan bahwa indikator pencapaian aktivitas siswa yang mencapai kategori baik (B) dapat diwujudkan bahkan pada siklus II rata-rata siswa mendapatkan kategori baik melebihi apa yang dicapai pada siklus I yang masih terdapat kategori kurang (D).

Rata-rata nilai hasil belajar siswa untuk kompetensi pengetahuan dan kompetensi keterampilan pada siklus II sebesar 75,17 dan 75,00 dengan ketuntasan belajar klasikal mencapai 90,00\% dan 87,00\%. Ratarata hasil belajar siswa pada siklus II untuk kompetensi pengetahuan mengalami kenaikan sebesar 18,00 dari siklus I yang hanya mencapai 57,17, sedangkan ketuntasan belajar siswa keseluruhan pada kompetansi pengetahuan pada siklus II naik sebesar 37\% yang sebelumnya mencapai 53\% pada siklus I. Sedangkan rata-rata hasil belajar siswa pada siklus II untuk kompetensi keterampilan juga mengalami kenaikan sebesar 10,90 dari siklus I yang hanya mencapai 64,10, sedangkan ketuntasan belajar siswa keseluruhan pada kompetansi pengetahuan pada siklus II naik sebesar $37 \%$ yang sebelumnya mencapai $50 \%$ pada siklus I.

Tabel 5. Hasil Belajar Siswa pada Kompetensi Pengetahuan dan Kompetensi Keterampilan Siklus I dan Siklus II

\begin{tabular}{clcccc}
\hline \multirow{2}{*}{ NO } & \multicolumn{1}{c}{ STATISTIK } & \multicolumn{2}{c}{ PENGETAHUAN } & \multicolumn{2}{c}{ KETERAMPILAN } \\
\cline { 3 - 5 } & & SIKLUS I & SIKLUS II & SIKLUS I & SIKLUS II \\
\hline 1 & Jumlah Siswa & 30 & 30 & 30 & 30 \\
2 & Jumlah Nilai & 1.715 & 2.255 & 1.923 & 2.250 \\
3 & Rerata Nilai & 57,17 & 75,17 & 64,10 & 75,00 \\
4 & Jumlah Siswa Tuntas & 16 & 27 & 15 & 26 \\
5 & Jumlah Siswa Tidak Tuntas & 14 & 3 & 15 & 4 \\
6 & Daya Serap & $57,00 \%$ & $75,17 \%$ & $64,10 \%$ & $75,00 \%$ \\
7 & Ketuntasan Belajar Klasikal & $53,00 \%$ & $90,00 \%$ & $50,00 \%$ & $87,00 \%$ \\
8 & Nilai Tertinggi & 75 & 85 & 100 & 85 \\
9 & Nilai Terendah & 25 & 60 & 7,69 & 65 \\
10 & Standar Deviasi & 16,38 & 7,82 & 32,57 & 6,43 \\
& & & & & \\
\hline
\end{tabular}

Indikator keberhasilan tindakan pada penelitian iniadalah sebesar 75 untuk kompetensi pengetahuan maupun keterampilan dan ketuntasan belajar klasikal sebesar 85\%. Hasil penelitian pada siklus II menemukan bahwa rerata nilai siswa pada kompetensi pengetahuan mencapai 75,17 dengan ketuntasan belajar klasikal sebesar 90,00\%. Sedangkan rerata nilai siswa pada kompetensi keterampilan mencapai 75,00 dengan ketuntasan belajar klasikal sebesar 87,00\%. Dengan demikian indikator keberhasilan tindakan penelitian yang ditetapkan telah tercapai pada siklus II.

Pendapat setuju pada pemanfaatan data transaksi keuangan DU/DI dalam pembelajaran ekonomi, yakni sebesar 86,33\%. Persentase ini jauh lebih dari siswa yang memberikan pendapat tidak tahu sebesar $8,67 \%$ dan tidak setuju yang hanya 5,00\%. Oleh karena rerata persentase pendapat siswa yang memiliki pendapat setuju terhadap pemanfaatan data transaksi keuangan DU/DI dalam pembelajaran ekonomi lebih besar dari 85\%, maka tindakan pada penelitian ini dinyatakan berhasil. Artinya, siswa merespon sangat positif terhadap pemanfaatan data transaksi keuangan DU/DI dalam menyusun siklus akuntansi.

\section{Pembahasan}

Berdasarkan hasil penelitian ditemukan bahwa indikator keberhasilan yang ditetapkan dapat dicapai setelah akhir siklus II. Hasil ini membuktikan bahwa pemanfaatan data transaksi keuangan Dunia Usaha/Dunia Industri dapat meningkatkan aktivitas dan hasil belajar siswa. Kondisi ini sejalan dengan yang diharapkan dimana kegiatan pembelajaran harus berpusat pada peserta didik untuk mendorong semangat belajar, motivasi, minat, kreativitas, inisiatif, inspirasi, inovasi dan kemandirian. Hal ini didukung dengan pemanfaatan sumber belajar yang berasal dari lingkungan sekitar yang berbasis pada Dunia Usaha/Dunia Industri sehingga mampu memberikan pengalaman belajar yang berbeda bagi siswa. 
Hasil penelitian ini sesuai dengan penelitian terdahulu, yang menemukan bahwa terdapat pengaruh pemahaman analisis transaksi terhadap ketuntasan siswa dalam menyusun jurnal. Kegiatan analisis ini menjadi proses dasar dalam meningkatkan aktivitas dan hasil belajar karena data transaksi yang diperoleh dari DU/DI akan dapat dicatat dengan baik dan benar ke dalam proses akuntansi lanjutan. Pemanfaatan DU/DI dalam proses pembelajaran juga dapat meningkatkan kemampuan profesional siswa dan pelajaran tambahan yang tidak didapatkan dalam pembelajaran di kelas. Kegiatan ini sesuai dengan penelitian lainnya bahwa praktik kerja industri dan motivasi berprestasi memiliki pengaruh yang signifikan terhadap tingkat keterampilan akuntansi. Sehingga apa yang didapatkan siswa pada DU/DI dapat dijadikan sumber belajar yang mampu mendukung kemampuan pengetahuan serta keterampilan siswa.

Pemanfaatan data transaksi pada DU/DI merupakan bentuk adaptasi pendidikan sistem ganda (PSG) yaitu dalam meningkatkan efisiensi proses pendidikan dan pelatihan tenaga kerja yang berkualitas professional sehingga diharapkan dengan menjadikan DU/DI sebagai sumber belajar maka kualifikasi kemampuan peserta didik pada 3 dimensi yaitu: sikap, pengetahuan, dan keterampilan mampu dicapai dengan baik (Permendikbud No 20. Tahun 2016).

Data transaksi keuangan yang diperoleh dari DU/DI menjadi sumber belajar yang sangat bermanfaat dalam memahami konsep akuntansi, menyajikan dan menerapkan siklus akuntansi sesuai dengan lingkup materi sehingga dengan data ini siswa memperoleh pengalaman belajar diluar pakem keilmuan yang hanya bersumber dari buku. Siswa mampu memahami secara riil konsep yang didapatkan dan mampu menyajikan laporan sesuai dengan tuntunan dunia kerja yang selalu dinamis. Dengan pemanfaatan data transaksi DU/DI ini akan memberikan wadah pengembangan perilaku yang mencerminkan karakter, tanggung jawab dan pembelajar sejati sesuai dengan tuntunan materi pembelajaran sebagai bentuk realitas kode etik akuntan yang memiliki integritas, objektivitas dan independen dalam menjalankan tugasnya.

Pada kegiatan awal pembelajaran dengan pemanfaatan data transaksi keuangan DU/DI, siswa belum mampu melakukan analisis transaksi yang diperoleh sehingga menyebabkan kurangnya kemampuan siswa melakukan tahapan lanjutan dalam akuntansi. Terdapat beberapa alasan yang menyebabkan terjadinya kondisi ini. Pertama, siswa belum mampu memahami langkah-langkah dalam mencari informasi data transaksi keuangan pada DU/DI yang mereka pilih. Kenyataannya, mereka hanya sekadar bertanya hanya pada data yang mereka inginkan bukan berdasarkan data penting yang nantinya bisa dijadikan sumber pencatatan. Kondisi ini menyebabkan data yang didapatkan masih sangat dangkal dan sederhana. Kedua, DU/DI yang mereka rujuk sebagai sumber informasi memperoleh data transaksi masih belum menerapkan sistem pencatatan akuntansi yang disarankan. Dengan tidak diterapkannya siswa pencatatan akuntansi yang benar dalam DU/DI tersebut secara realitas pasti tidak ada data yang valid untuk diolah menjadi sumber transaksi, kenyataannya siswa masih dapat memperoleh informasi data keuangan. Kondisi ini menyebabkan data yang diolah ke dalam transaksi sifatnya masih informasi umum bukan dari sumber transaksi yang ada. Selain itu juga, dengan data yang masih bias ini menyebabkan konsep analisis dan kegiatan dalam menyajikan siklus akuntansi masih sangat kurang dipahami oleh siswa. Ketiga, dalam memperoleh data transaksi keuangan pada DU/DI tidak semua siswa terlibat secara aktif, kenyataannya dalam kegiatan kelompok ini masih mengandalkan satu orang atau dua orang siswa untuk bertanya tentang data yang diperlukan. Kondisi ini menyebabkan tidak semua informasi yang diperlukan dapat dicatat dengan baik dan tidak semua sumber transaksi yang teridentifikasi dengan benar. Mereka juga akhirnya tidak mendapatkan hasil belajar yang baik karena konsep tahu bahwa dan tahu bagaimana tidak dapat dikembangkan dengan seimbang.

Pemanfaatan data transaksi keuangan pada DU/DI memberikan arah dalam pengembangan life skill kepada siswa, karena sumber belajar diartikan sebagai segala tempat atau lingkungan sekitar, benda, dan orang yang mengandung informasi, dapat digunakan sebagai wahana bagi peserta didik untuk melakukan proses perubahan tingkah laku. Proses perubahan ini adalah pada aktivitas siswa yang diyakini mampu memberikan dampak yang positif dalam perkembangan mental dan kepribadian siswa secara umum. Dengan memanfaatkan data dari DU/DI dalam diskusi, siswa terlihat antusias mengikuti proses pembelajaran sehingga keterlibatan siswa dalam pembelajaran meningkat. Kegiatan pembelajaran didominasi oleh aktivitas siswa yang mengarah pada student center oriented.

Data transaksi yang didapatkan dari DU/DI diharapkan mampu mengakomodasi semua tuntunan kompetensi dasar, terutama indikator yang menjadi acuan dalam pelaksanaan penilaian (Panduan Penilaian SMA, 2017) oleh karena itu, siswa diarahkan pada DU/DI yang menjadi rujukan dalam arti guru menunjuk DU/DI yang ada di daerah sekitar sekolah yang memiliki proses pencatatan transaksi dan mau bekerjasama dengan pihak sekolah sebagai bentuk keterlibatan masyarakat untuk mendukung proses pendidikan. Data yang didapatkan menjadi lebih spesifik dan semua siswa menjadi ikut terlibat karena terlebih dahulu sudah mendapatkan pembagian tugas untuk mencatat dan memperoleh informasi berkaitan dengan data transaksi keuangan. Kegiatan ini tidak terlepas dari sudut proses kegiatan dari 
akuntansi yaitu setelah mengidentifikasi selanjutnya akan dilakukan kegiatan memproses atau menganalisis data yang relevan yang diperoleh dari sumber transaksi keuangan.

Dengan adanya data yang relevan dan sesuai dengan indikator pencapaian kompetensi maka langkah analisis transaksi dan kegiatan menyajikan pencatatan siklus akuntansi sesuai dengan kompetensi keterampilan dapat dilaksanakan dengan baik dan sesuai harapan. Akibatnya, pengetahuan siswa menjadi lebih terbuka dan lebih luas dan dari pengetahuan yang diperolehnya dengan pemanfaatan data transaksi keuangan DU/DI ini diyakini dapat memperkuat pemahaman siswa terhadap materi pelajaran sehingga hasil belajar siswa mengalami peningkatan. Hal ini sesuai dengan hasil kajian yang menyatakan bahwa kompetensi peserta didik yang merupakan sesuatu yang melekat dalam dirinya yang dapat digunakan untuk memprediksi tingkat kinerjanya, sesuatu itu bisa menyangkut motif, konsep diri, sifat, pengetahuan maupun keahlian serta pemanfaatan data transaksi keuangan DU/DI ini dapat mengarahkan siswa ke dalam rasa ingin tahu yang tinggi, menumbuhkembangkan kemampuan intelektual dalam berpikir induktif, kemampuan meneliti, kemampuan berargumentasi, dan kemampuan mengembangkan pengetahuan.

Dari fakta-fakta yang disajikan, menunjukkan bahwa pemanfaatan data transaksi keuangan DU/DI sangat baik digunakan dalam kegiatan pembelajaran ekonomi khususnya pada materi akuntansi.

\section{Simpulan dan saran}

\section{Simpulan}

Berdasarkan hasil penelitian dan pembahasan dapat disimpulkan bahwa pemanfaatan data transaksi keuangan Dunia Usaha/Dunia Industri pada mata pelajaran Ekonomi kelas XII IPS 1 SMA Negeri 2 Busungbiu semester ganjil tahun pelajaran 2017/2018 dapat meningkatkan aktivitas dan hasil belajar siswa. Hal ini dapat dilihat dari rerata skor aktivitas siswa yang sudah mencapai kategori B dan hasil belajar yang mencapai rerata 75 dan ketuntasan belajar sebesar $85 \%$ pada akhir siklus. Pada skor aktivitas hasil belajar siswa yang mencapai kategori cukup $(56,54)$ pada siklus I menjadi kategori baik $(66,96)$ pada siklus II, sedangkan hasil belajar siswa rerata nilai siswa pada kompetensi pengetahuan sebesar 57,17 dengan ketuntasan belajar klasikal sebesar 53,00\% pada siklus I menjadi sebesar 75,17 dengan ketuntasan belajar klasikal sebesar $90,00 \%$ pada siklus II. Sedangkan rerata nilai siswa pada kompetensi keterampilan sebesar 64,10 dengan ketuntasan belajar klasikal sebesar 50,00\% pada siklus I menjadi 75,00 dengan ketuntasan belajar klasikal sebesar $87,00 \%$. Untuk pendapat siswa yang memberikan pendapat positifmelebihi inidikator kinerja minimal 85\%, dimana sebanyak 86,33\% siswa menyatakan setuju, 8,67\% menyatakan tidak tahu dan hanya $5 \%$ yang menyatakan tidak setuju terhadap pemanfaatan transaksi keuangan Dunia Usaha/Dunia Industri pada mata pelajaran Ekonomi.

\section{Saran}

Berdasarkan temuan-temuan yang diperoleh dalam penelitian ini, maka dapat diajukan beberapa saran-saran yaitu : guru-guru dapat memanfaatkan lingkungan sekitar sebagai sumber belajar dalam upaya meningkatkan pemahaman konsep mata pelajaran, dan disarankan juga kepada para guru untuk merubah paradigma teacher centered menjadi student centered, serta merubah paradigma guru dari guru sebagai pusat informasi menjadi guru sebagai fasilitator dan mediator pembelajaran.

\section{Daftar Rujukan}

Permendikbud No. 24 Tahun 2016 tentang Kompetensi Inti dan Kompetensi Dasar Pelajaran pada Kurikulum 2013 pada Pendidikan Dasar dan Pendidikan Menengah

Sudjana, N. 2008. Penilaian Hasil Proses Belajar Mengajar. Bandung:PT. Remaja Rosdakarya

Soejanto, Agoes. 1995. Bimbingan Kearah Belajar yang Sukses, Jakarta: Rineka Cipta.

Permendikbud No. 22 Tahun 2016 tentang Standar Proses Pendidikan Dasar dan Menengah

Sumarsono. 2007. Strategi Belajar Mengajar. Surakarta: UNS

Wijaya, I K. 2006. Penerapan Penilaian Portofolio dalam Pembelajaran Matematika yang Berbasis Group Investigation (GI) untuk Meningkatkan Kompetensi Dasar Siswa Kelas X3 Semester Genap SMA Laboratorium IKIP Negeri Singaraja Tahun Ajaran 2005/2006. (Skripsi). Tidak diterbitkan. Jurusan Pendidikan Matematika, IKIP Negeri Singaraja.

Bastian, Indra. 2006. Akuntansi Sektor Publik: Suatu Pengantar, Jakarta: Erlangga.

Permendikbud No. 22 Tahun 2016 tentang Standar Proses Pendidikan Dasar dan Menengah

Putu Agus Sedana Jaya /Pemanfaatan Data Transaksi 
Fitriani, Umi, 2011. Pengaruh Pemahaman Analisis Transaksi Terhadap Ketuntasan Siswa dalam Menyusun Jurnal di Kelas XI Jurusan Akuntansi SMK Pembangunan Kecamatan Bagan Sinembah Kabupaten Rokan Hilir. Fakultas Tarbiyah Dan Keguruan Universitas Islam Negeri Sultan Syarif Kasim Riau. Pekanbaru

Yana, Enceng. 2015. Pengaruh Praktek Kerja Industri dan Motivasi Berprestasi terhadap Keterampilan Akuntansi Siswa pada Mata Pelajaran Akuntansi (Penelitian pada siswa Kelas XII di SMK Kota Cirebon).Pendidikan Ekonomi Unswagati Cirebon

Depdikbud. 1994. Konsep Sistem Ganda pada Pendidikan Menengah Kejuruan di Indonesia. Jakarta: Depdikbud

Permendikbud Nomor 20 Tahun 2016 tentang Standar Kompetensi Lulusan Pendidikan Dasar dan Menengah

Permendikbud No. 21 Tahun 2016 tentang Standar Isi Pendidikan Dasar dan Menengah

Moeslihat, Rahmat. 2011. Akuntansi Untuk SMA Kelas XII. Jakarta: Regina

Majid A. 2009. Perencanaan Pembelajaran. Bandung: Remaja Rosdakarya

Jusup, Al Haryono. 2005. Dasar-dasar Akuntani Jilid 1. Yogyakarta : Bagian Penerbitan STIE YKPN

Mangesa, Riana T. 2009. Kajian Terhadap Pola Pendidikan Berorientasi Kompetensi Dunia Industri dalam Penyiapan Tenaga Kerja. FT UNM: Jurnal Medtek Vol 1. No 2.

Adnyana, Gede Putra. 2013. Penerapan Video Eksperimen Dan Animasi Untuk Meningkatkan Pemahaman Konsep Kimia Siswa Aspek Makroskopis, Mikroskopis, Dan Simbolis. PTK. SMA Negeri 2 Busungbiu. 